\title{
Improving the technological support of dairy cattle breeding
}

\author{
Olga Kondratieva*, Anatoly Fedorov, Olesya Slinko, Vyacheslav Voytyuk
}

Russian Research Institute of Information and Feasibility Study on Engineering Support of Agribusiness, Federal State Budgetary Scientific Institution (Rosinformagrotekh FSBSI), 60, Lesnaya Str., Pravdinsky Township, 141261 Moscow Region, the Russian Federation

\begin{abstract}
The paper discusses the issues of providing the population of the Russian Federation with milk and dairy products, increasing milk production, and implementing investment projects in the industry. It is noted that the technological and technical support, as well as improving the systems of keeping, feeding and milking animals play an important role in solving problems of increasing the efficiency of dairy farming. Particular attention is paid to the introduction of innovative technologies and modern machinery at dairy farms and facilities, including equipment fitted with digital systems for collecting information about the state of animals, milk yield, milking parameters and other indicators, as well as robots. Milking installations provided by the system of machines are designed for milking cows in stalls, milking parlors, as well as in maternity wards. According to their engineering level, they must ensure the fulfillment of the physiological milk let-down requirements, the productive longevity of animals, etc. The developed artificial intelligence system allows planning the efficiency of feeding and monitoring the main processes at a dairy farm. Feed is of paramount importance in the prime cost of raw milk. The cost of feed affects the profitability of production. Spectrometers, including pocket ones, can be used for feed analysis. Improvement of technologies in dairy production will help to increase the competitiveness of the industry.
\end{abstract}

\section{Introduction}

Ensuring the food security of the country, while providing the population with high-quality food products and the industry with raw materials, is impossible without technological modernization of agriculture, as well as without the introduction of innovative resourceenergy-efficient technologies using high-performance machinery and equipment based on the achievements of science and practice [1].

Dairy cattle breeding has been and remains an important industry for the Russian economy and makes a significant contribution to the country's food security. Currently, the Russian Federation is one of the world's largest milk and dairy product manufacturing countries. Dairy farming has a great economic impact on all agriculture; therefore milk production is of great national economic importance providing the main product for the human diet $[2,3]$.

In recent years, the consumption of dairy products in Russia has been significantly lower than the standards recommended by the Ministry of Health of Russia (325 $\mathrm{kg}$ per person annually.) The consumption of milk and dairy products was about $234 \mathrm{~kg}$ per capita annually in 2019-2020 [4]. According to the materials of the XII Congress of the National Union of Milk Producers (Soyuzmoloko), the consumption of dairy products increased by $3 \%$ (to 29.3 million metric tons) in Russia in 2020, which is 800,000 metric tons more than that in 2019. At the same time, the average per capita indicator has reached its maximum value for the last 7 years (since the beginning of the sanctions) [5].

According to the preliminary results of 2020, the production of raw milk increased by $2.7 \%$, i.e. up to 32.2 million metric tons; the production of commercial milk increased by $4.6 \%$ (up to 23.5 million metric tons); the production of drinking cream increased by $15 \%$; the production of ice cream and dry whey increased by $14 \%$ each; the production of cheeses, butter and skimmed milk powder increased by $5 \%$ each; the production of sour cream increased by $3 \%$; the production of drinking milk increased by $2 \%$ [6].

The main task of the industry is to intensify dairy production and to increase the productivity of animals, which is achieved, among other things, through the modernization of dairy facilities.

\section{Problem statement}

The accelerated development of dairy cattle breeding and an increase in milk production should be considered as a problem of national importance, the solution of which will allow satisfying the demand for milk and dairy products at the expense of domestic production in

*Corresponding author: inform-iko@mail.ru 
the future scientifically and in the interests of the population [7].

According to the MilkNews analytical center and the National Union of Milk Producers, 20 constituent entities of the Russian Federation account for $64 \%$ of the production of drinking milk in the country. Top 5 includes: Republic of Tatarstan (249,600 metric tons or $+12 \%)$, Krasnodar Territory (304,800 metric tons or $2 \%)$, Krasnoyarsk Territory $(228,500$ metric tons or $0.4 \%)$, Sverdlovsk region $(219,300$ metric tons or $-3.8 \%)$ and Moscow $(225,400$ metric tons or $-8.1 \%)$. The fastest production growth rates equal to $16 \%$ were recorded in the Sakhalin Oblast. The Kemerovo region was noted, where the production of drinking milk decreased by $32.9 \%$ at the beginning of 2020 as compared to the same period in 2019 and amounted to 33,600 metric tons [8].

To increase milk production, technological and technical support for the development of dairy cattle breeding, including keeping cows, feeding, milking, etc., is of great importance.

The solution of this problem will be facilitated by the implementation of the "Agricultural machinery and equipment" subprogram of the Federal Scientific and Technical Program for the Development of Agriculture for 2017-2025 [9].

\section{Purpose of the research}

The purpose of the study is to analyze the technical and technological support of dairy farming.

\section{Research materials and methods}

During the research, information was used from the publications of the Ministry of Agriculture of Russia, from journals, from the websites of the leading scientific and educational institutions of the Ministry of Education and Science of Russia, and other organizations, where research results and information on the development of dairy cattle breeding are provided.

The research was performed using analytical, comparative and information-logical methods for analyzing the initial information.

\section{Research results and discussion}

According to the operational data of the Ministry of Agriculture of Russia, as of $03 / 15 / 2021$, the average milk yield from one cow per day amounted to $18.02 \mathrm{~kg}$ $(+0.86 \mathrm{~kg})$ as compared to the same period last year, and the daily amount of milk sold by agricultural organizations was 49,6700 metric tons, which is $4 \%$ (1,890 metric tons) more [10]; gross production of raw milk increased by $0.9 \%$ (up to 4.3 million metric tons), and commercial milk amount increased by $1.8 \%(+0.1$ million metric tons) according to preliminary estimates. According to analysts, the increase in milk production in recent years is due to the introduction of new facilities and to an increase in the milk productivity of cows and the level of marketability. In 2021, the long-term growth trend in the production of commercial milk will continue against the background of the introduction of new facilities and the intensification of production. The increase may be about 3\% (approximately 0.8 million metric tons.)

Investments contribute to an increase in the level of technological support for dairy farming. In 2020, the dairy industry became the second in terms of investment activity in the agricultural sector in the growth rating of livestock subsectors according to experts from the Center for Industry Expertise of the Russian Agricultural Bank.

The main area of increasing efficiency, reducing losses of dairy products and improving their quality, is to ensure the efficiency and functioning of dairy farms and facilities. Therefore, one of the most important tasks of the engineering and maintenance services at dairy farms and facilities is the use of modern equipment and technological solutions.

The main thing in improving the material and technical support of the milk production process in agricultural enterprises is a high-tech energy-efficient production system: storing feed; maintenance and mechanized feeding and milking of animals; creation of farms with waste heat recovery and disposal of waste products (robotic farms); computerization of the processes of accounting for milk production and forecasting the genetic value of animals; control of milk quality using electronic means (testing of fat and protein content in milk); milk cooling and storage systems, etc.

To do this, the industry is implementing a system of machines and equipment for cattle farms and facilities (more than 100 machines and installations are produced), using which 30 types of work are performed.

In Russia, the equipment and technologies from DeLaval, a Swedish company, from Lely, a Dutch company, and from GEA, a German company, are used to a greater extent. There are about a thousand robots for voluntary milking. They occupy $0.07 \%$ of the total market volume.

The most promising items of digitalization in dairy farming are large dairy facilities having a livestock of more than 800 cows (about $4.3 \%$ of the total number of farms), which account for more than $30 \%$ of milk produced in Russia [11, 12]. These enterprises mainly use imported platform solutions: milking equipment fitted with digital systems for collecting and processing information about individual indicators of animals (milk yield, health status, hunting, etc.); automated rationed animal feeding systems integrated into the overall farm management system [13].

In case of tie-up keeping of livestock, the economic effect of milk production technology can be implemented using the integrated mechanization of the following main processes: water supply of farms and auto-drinking of animals; robotic milking of cows; preparation and distribution of feed; manure removal, etc.

Kurganselmash OJSC, Femax Research and Production Enterprise, VIM, Chelno-Vershiny MachineBuilding Plant OJSC have developed and are manufacturing state-of-the-art milking installations, such 
as UDM-100 and UDM-200, fitted with a milk pipe made of stainless steel. These installations feature a number of joints reduced 3 times, a stable vacuum condition and maintenance reduced as compared to ADM-8 installations. The models have been upgraded through equipping them with automated milking machines fitted with the UDM-100 / 200A milk flow meters. The UDM-200 installation is recognized as the leader among peers, including foreign ones, as to all criteria (price and quality) [14].

To replace the automated installations equipped with the $2 \times 4$ UDA-8A Tandem milking stalls with the 2x8UDA-16A Yolochka milking stalls, researchers and designers from VIM and Femax Research and Production Enterprise have developed and mastered the production of the new UDE-M Yolochka 03E Modular Type automated milking installations fitted with an electronic control system for the milking process and an automatic system for collecting and operational data storage [15].

The Stimulus system as part of the UDE-M Yolochka automated milking machine performs correct shutdown of the teatcups, removal and removal of the milking clusters after milking with a decrease in milk let-down intensity below $200 \mathrm{~g} / \mathrm{min}$ after a 30-second delay, provides obtaining individual milk production schedules, receiving, storing and reading information from electronic milking control units in automatic mode without the presence or switching on of a computer, generating and storing milking protocols, transmitting electronically individual milking data to the Selex herd management computer systems and to the Breeding Workstation.

The basic modification of the Yolochka milking machine has passed state acceptance tests at a machine test station and is recommended for use (Table 1) [14].

Table 1. Main specifications of an automated installation equipped with UDE-M Yolochka milking stalls.

\begin{tabular}{|l|c|}
\hline \multicolumn{1}{|c|}{ Parameters } & Values \\
\hline $\begin{array}{l}\text { Number of cows milked for 1 hour of } \\
\text { regular time, heads }\end{array}$ & 50 to 96 \\
\hline Size of the serviced herd, heads & 100 to 800 \\
\hline Number of: & 2 two rows by 4,6, \\
- milking locations & $8,10,12,16,18$ \\
- milking units & $8,12,16,20,24$, \\
& 32, and 36 \\
\hline Weight, kg & 3,500 to 4,500 \\
\hline Number of operators. & 1 to 2 \\
\hline
\end{tabular}

Milking systems for milking cows in stalls and parlors, as well as in maternity wards, take a key place in the machine system. Their state of the art should ensure the fulfillment of the physiological requirements of milk let-down, minimum resource consumption for the implementation of processes, high quality milk, animal health and productive longevity of cows. To milk cows, various organizational forms of process performance are provided, e.g. in barns with collection of milk in buckets and a milk pipe, in milking parlors using milking machines of various designs, in conveyor milking installations, pasture milking installations, and in automated installations for free milking.

Installations for milking cows in a milk pipeline must ensure the following process steps: automated milking of animals with stimulation of the milk flow reflex and transfer to a reduced vacuum level at the end of milking; individual and group registration of milk yields, data transfer to a computer; transportation and cleaning of milk and automatic circulation flushing of equipment before and after milking; automatic flushing and lifting of the milk arch above the feed alley. In recent years, milking machines as dairy production lines, in which milk is transported through an underground pipeline immediately after milking to the dairy over a distance of several kilometers have become widespread in Germany and other countries. During the passage through the underground milk pipeline, the milk is cooled to the required temperature [14].

The upgrading of Yolochka milking units provides for the creation of a new design of an automated handling mechanism fitted with udder quarter milking control, including individual milking cup holders installed as a common assembly on an electrically driven controlled handling arm, sensor counters for udder quarter milk flow control, individual electromagnetic pulsators for each teat cup, and a control system. The system of machines provides for the creation of the UDE-M Yolochka (04Ch version) automated milking unit equipped with an electronic control system for the milking process for cow individual udder quarters, an automatic system for data collection and operational data storage with subsequent transmission in digital form to a computerized herd management system.

The System of machines also provides for the creation of the high-performance Carousel conveyor and ring milking installations based new components and intended for facilities having a capacity of 800 and more cows, which will provide individual service for animals (Table 2).

The unit should be equipped with handling mechanisms that perform the udder quarter milking process, as well as it should accommodate Yolochka milking stalls, a sanitary milk pipeline for removing abnormal milk, a sanitary point for cleaning the udder of cows at the entrance to the unit or mechanized means for cleaning teats and removing the first streams directly in milking stalls. It also should have a controlled variable frequency drive that ensures the optimal rotation speed of the milking platform depending on the individual duration of milking the cows.

The system of machines provides for an automated milking machine (UDP) equipped with parallel walkthrough milking stalls and a digital flow meter for milk quality control. The milking machine is intended for machine milking of cows in parallel-walk milking stalls along with delivering concentrated feed in case of tie-up and loose cow housing, as well as when keeping cows in fly camps.

The UDP milking unit features a collapsible design of milking stalls using multipurpose fasteners and a DN1 1/2" galvanized pipe, which can significantly increase its operational reliability and durability, 
transportation and installation. It is most effective and expedient to use it in the premises of dairy farms and in fly camps. Plant capacity per milking parlor is 8 cows per hour [14].

Table 2. Specifications and performance of the Carousel conveyor and ring milking installations.

\begin{tabular}{|c|c|}
\hline Parameters & Values \\
\hline Number of milking stalls & 24 to 40 \\
\hline Number of milking machines & 24 to 40 \\
\hline $\begin{array}{l}\text { Number of serviced animals, } \\
\text { heads }\end{array}$ & 600 to 1,000 \\
\hline Number of service staff & 1 to 3 \\
\hline $\begin{array}{l}\text { Productivity, milking per } \\
\text { cow per hour }\end{array}$ & 100 to 200 \\
\hline $\begin{array}{l}\text { Working vacuum pressure, } \\
\mathrm{kPa}\end{array}$ & $48 \pm 1$ \\
\hline Installed power, $\mathrm{kW}$ & Max. 20 \\
\hline $\begin{array}{l}\text { Milking machine milk let- } \\
\text { down method }\end{array}$ & Individual udder quarter \\
\hline Milk production recording & $\begin{array}{l}\text { Individual for each share } \\
\text { of the udder quarter }\end{array}$ \\
\hline Milk quality control & $\begin{array}{l}\text { By electrical conductivity } \\
\text { with abnormal milk being } \\
\text { discharged into a sanitary } \\
\text { milk pipeline }\end{array}$ \\
\hline Washing process control & Automatic \\
\hline Service life, years & 7 \\
\hline MTBF, hours & 50,000 \\
\hline Availability ratio & 0.98 \\
\hline $\begin{array}{ll}\text { Labor intensity } & \text { of } \\
\text { installation, } & \text { man-h }\end{array}$ & 220 \\
\hline $\begin{array}{l}\text { Every shift operational time } \\
\text { of maintenance, man-h }\end{array}$ & 0.2 \\
\hline
\end{tabular}

Given the trend towards large dairy farms, many robot milking companies have started building robotic conveyor ring milking machines. DeLaval has built the world's first AMR 24-milking-stall robotic conveyor system.

To perform preparatory and final operations, 5 robotic manipulators are installed inside the circle. After completing the operations, the conveyor is stopped. Another milking conveyor robotization has been the use of the GEA robotic installation, where a self-contained milking robot is installed in each milking location. The closed-type milk cooler tanks provided by the machine system have to ensure the following operations: milk cooling to a predetermined temperature in manual or automatic mode; storage of milk with maintenance of the set temperature; stirring milk during cooling and storage; determination of the amount of milk in the tank; circulating rinsing and disinfection of the milk bath; emptying the tank.

The design of tanks should comply with the requirements of ISO 5708-83 in terms of direct cooling tanks, exclude the possibility of ice formation in milk when the bath is filled by $20 \%$ or more of the nominal capacity, ensure that the cooling system is turned off when the milk temperature drops to $4{ }^{\circ} \mathrm{C}$ and it is turned on when milk temperature is maximum $5{ }^{\circ} \mathrm{C}$.

The machine system includes a mobile medical milking machine for exposure to a high-frequency electromagnetic field intended for the prevention and treatment of mastitis. The basis for its development is the need to use environmentally friendly physiotherapeutic methods and devices without antibiotics for the prevention and treatment of cow mastitis, affecting $10 \%$ to $40 \%$ of the livestock. In current conditions of milk production, the relevance of environmentally friendly technology without drug treatment of the udder of cows is increasing. It provides a therapeutic effect of a highfrequency electromagnetic field (HF EMF) on the udder of cows for the treatment of various forms of mastitis, diseases of the skin and subcutaneous tissue of the udder.

Feed is one of the key contributors to the cost of raw milk. Its costs directly affect the profitability of production and can reach up to $50 \%$ of the production costs. To perform a quick analysis of the feed quality, SCIO an Israeli company, has developed portable (pocket) spectrometers. Using the spectrometer, one can check the feed in the field, directly in the silo or hangar. The device determines moisture, dry matter, protein, energy value and fats. The owner sees the analysis results on his/her phone.

Mustang Feeding Technologies, together with ALAN-IT, their partner, developed an artificial intelligence (AI) system based on Microsoft in Russia in 2018. The technology allows planning the efficiency of feeding. The AI system solves a large number of tasks and monitors the main processes on the farm: carries out online monitoring of the milk production process; monitors the herd, reproduction, diseases and deaths; prepares analytical reports; determines the factors that affect production (temperature, diet); forecasts milk production and livestock production; identifies unproductive cows; determines the influence of personnel on the milk production process; builds personnel motivation systems based on production data. Based on the individual cow number in the system, one can see all the data on the animal starting from birth regarding calving, vaccinations, treatment periods, groups into which it has been transferred, the amount of milk for each lactation, how the calving has been performed, what newborn calf sex is, and by whom the cow has been inseminated. All statistics of the animal's vital activity are computerized [16].

Nedap, a Dutch company, has developed augmented reality glasses for a dairy farm (Microsoft HoloLens are integrated inside the glasses). Using special collars, the system collects information about the cows. The farmer can find out about the condition of the animal simply by looking at it through the special glasses.

The farmer has onscreen access to data regarding the reproductive system, health indicators and temperature. As the farmer moves around the barn, information adapts to farmer's movements and appears over the head of the animal in a convenient format. If the farmer needs to make a mark, then using voice commands or gestures, the farmer transmits the decision to the system. According to the developers, such an interface allows the farmer to collect information about the animal without being distracted from the main work [16]. 


\section{Conclusions}

Improving the livestock system components (loose keeping of animals, milking cows in modern milking installations, feeding cows with complete feed mixtures, comprehensive mechanization of labor processes) allows increasing the productivity of dairy herds by $4 \%$, increasing twice the number of cows served by a single worker. Analysis of machine processes and equipment shows that a number of types of up-to-date equipment are required for technological modernization and equipping of reconstructed dairy farms and newly built ones having a livestock of over 1,200 cows. At the same time, it is necessary to manufacture Russian equipment. The feasibility of developing and mastering new types of high-tech equipment in Russia is confirmed by the results of the use of many high-performance installations: the cost of domestic machines is significantly lower than that of imported peers (1.4 to 1.6 times); the operational cost of imported milking machines is 1.5 times higher than that of domestic counterparts.

The use of innovative solutions in dairy farming by the example of the best farms in Russia made it possible to increase their efficiency and solve the problem of replacing imported products with domestic ones.

\section{References}

1. O. V. Kondratieva, A. D. Fedorov, Technological modernization is the key to the successful development of agriculture, Innovative technologies in science and education (ITNO-2017), Proceedings of the $\mathrm{V}$ Int. scientific and practical. conf. (Publishing house of DGTU-PRINT LLC, Rostovon-Don) pp. 416-419 (2017)

2. V.N. Kuzmin, Organizational and economic mechanism for the development of beef cattle breeding in Russia, Machinery and technologies in animal husbandry, 3, 98-101 (2020)

3. Kh.A. Amerkhanov, The state and development of dairy cattle breeding in the Russian Federation, Dairy and meat cattle breeding, 1, 2-5 (2017)

4. MilkNews, retrieved from: https://milknews.ru/ (accessed on 03.24.2021)

5. The consumption of dairy products increased by 800,000 metric tons in 2020, retrieved from: https://souzmoloko.ru/news/rinokmoloka/Potreblenie-molochnoj-produkcii-v-2020godu-uvelichilos-na-800000-tonn.html (accessed on 04.05.2021)
6. Raw milk production increased by $2.7 \%$ in 2020 , retrieved from: https://milknews.ru/analitika-rinkamoloka/rinok-moloka-v-Rossii/proizvodstvosyrogo-moloka-2020.html (accessed on 05.05.2021)

7. N.N. Shumeiko, Efficiency of using domestic dairy cattle breeds, Economy of agriculture of Russia, 7, 58-65 (2018)

8. The dairy industry ranked second in terms of investment activity in the agricultural sector in 2020 - Rosselkhozbank, retrieved from: https://www.dairynews.ru/news/molochnaya-otraslstala-vtoroy-po-investitsionnoy-.html (accessed on 04.02.2021)

9. Federal Scientific and Technical Program for the Development of Agriculture for 2017-2025, retrieved from: https://minobrnauki.gov.ru/about/deps/dkdovssn/dkd ovssninfo/federalnaya-nauchno-tekhnicheskayaprogramma-razvitiya-selskogo-khozyaystva-na2017-2025-gody/ (accessed on 04.05.2021)

10. The milk sales in agricultural organizations increased by 4\%, retrieved from: https://mcx.gov.ru/press-service/news/obyemrealizatsii-moloka-v-selkhozorganizatsiyakh-vyrosna-4/ (accessed on 03.23.2021)

11. T.E. Marinchenko, Digitalization as a driver of development of domestic animal breeding, IOP Conference Series: Materials Science and Engineering, 873(1), 012004 (2020)

12. A.D. Fedorov, O.V. Kondratieva, O.V. Slinko, Process of digital transformation of agrarian economy, Advances in Economics, Business and Management Research, 7, 164-169 (2020)

13. T.E. Marinchenko, Promising developments in the field of dairy cattle breeding, Machinery and technologies in animal husbandry, 2(38), 124-129 (2020)

14. L.P. Kormanovsky, Yu.A. Tsoi, V.V. Kirsanov, Areas of development of a system of machines for dairy cattle breeding, Machinery and technologies in animal husbandry, 1(37), 14-23 (2020)

15. UDE-M Yolochka milking machine (milking parlor), retrieved from: https://viesh.ru/oborudovanie-dlyamolochnih-ferm/doilnie-ustanovki/elochka/ (accessed on 04.05.2021)

16. Dairy market news, retrieved from: https://milknews.ru/longridy/pjat-novyh-tehnologijkotorye-menjajut-molochnoe-zhivotnovodstvo.html (accessed on 04.05.2021) 